\section{Minerals Causing Silicosis}

$\mathrm{P}^{\mathrm{T}}$ RACTICALLY all types of dust fibrosis of the lungs are now known to be manifestations of the presence of silicon, though in the older textbooks several forms of pneumoconiosis are described according to the different dusts which were supposed to have produced them. Usually the element is present in the form of the oxide silica, and it is generally held that, with the exception of the silicate asbestos, the more complex compounds of silicon are incapable of producing the disease.

There is evidence that this view of the question is perhaps too limited, and in a recent paper Dr. W. R. Jones ("Silicotic Lungs: The Minerals they Contain", J. Hygiene, 33, No. 3, 307 ; 1933) even goes so far as to suggest that a silicate, sericite, plays a far greater part in the production of silicosis than silica itself. He finds that in the rocks and materials exploited in the industries in which silicosis is a recognised hazard, silica is combined with a fibrous silicate, sericite, the hydrous silicate of aluminium and potassium. On the other hand, there is no sericite in the gold-bearing quartz of the Kolar goldfield, India, or in the sandstone of certain Scottish collieries, and in these mines silicosis is said not to occur.

Further, Dr. Jones finds that the bulk of the mineral residue obtained from silicotic lungs consists of sericite; quartz particles also occur in these lungs, but they are nothing like so numerous as the minute sericite particles. There would seem to be no doubt that quartz is capable of producing fibrosis of the lungs-recent experimental work alone shows this-but Dr. Jones suggests that in the majority of cases sericite plays by far the more important part.

In South Africa, where Dr. Jones has recently described his theory, his views may perhaps have only academic interest; but in Great Britain, where industrial conditions are more complex, they may, if substantiated, be of great practical importance, and it is clear that they must receive serious consideration.

\section{University and Educational Intelligence}

Cambridge.-H. E. Tunnicliffe, of Gonville and Caius College, has been elected University lecturer and G. A. Millikan University demonstrator in the Department of Physiology.

The General Board recommends that there shall be established a Shield readership of pharmacology, the stipend of which shall be $£ 1,100$ a year.

The Managers of the Benn W. Levy Fund have appointed J. Yudkin, Hackney Downs School and Christ's College, to the studentship for research in biochemistry.

C. H. Waddington, of Sidney Sussex College, has been elected to a research fellowship at Christ's College.

London.-The Middlesex County Council has made a building grant of $£ 100,000$, payable over ten years, to the University towards the cost of erecting new University buildings on the Bloomsbury site. The grant is subject to certain conditions, one of which is that the new building for the University Central Library shall be associated with the name of the County of Middlesex. Grants have also been made by three more of the City Companies, namely, the Cordwainers, the Innholders and the Farriers, towards the Hall.

OxFoRD.-At his installation as Chancellor of the University on December 7, Lord Irwin took occasion to recall the eminence of his predecessor, Lord Grey of Falloden, as a field naturalist. With an apposite adaptation of a line from the Odyssey, the Chancellor went on to say that Lord Grey's intimate knowledge of the habits, movements and song of beasts, fishes and birds respectively, suggested that Nature herself had inspired him with the quintessence of her own wisdom.

In the annual report, just issued, of the Curators of the Bodleian Library, mention is made of the approaching completion of the extension of the Science Library. The new building will ultimately provide 120 additional seats for readers. More space is available for the storage of scientific books than will be required for some years; and meanwhile the building will be able to accommodate temporarily the overflow from other parts of the Library.

THE annual meeting of the Mathematical Association will be held at the Institute of Education, Southampton Row, London, W.C.1, on January 4-5, under the presidency of Prof. G. N. Watson. On January 4, Prof. Watson will deliver the presidential address, entitled "Scraps from some Mathematical Notebooks". On January 5 a discussion on "Mathematics in Central Schools" will be opened by Mr. G. T. Clark and one on "Teaching of Differentials" by Prof. G. Temple. Further information can be obtained from Mr. C. Pendlebury, 39 Burlington Road, Chiswick, London, W.4.

Educational films stand to gain largely in the volume and extent of their influence through the results of a conference held on the invitation of the League of Nations at Geneva on October 5-11, 1933, for facilitating the international circulation of films of an educational character. A convention was drawn up providing for the exemption from Customs duties of films having "eminently international educational aims". In the machinery prescribed for giving effect to the convention, an important rôle is to be played by the International Educational Cinematographic Institute, represented at the conference by its director, Dr. Luciano de Feo. Every film (including 'talkies') for which exemption from customs duties is to be claimed, will have to be submitted for certification to the Institute, although the actual grant of exemption will be accorded in each case by the competent national authority. The Institute will publish catalogues of certificated films and the parties to the convention will encourage the circulation of the catalogues. The convention has already been signed by plenipotentiaries on behalf of Great Britain, India, Italy and seven other countries. The conference further recommended the reduction or abolition of charges for the transport of such films and the extension of Customs facilities to the posters advertising them. It is noteworthy that the preamble to the convention specifies the "encouragement of moral disarmament" as a principal benefit to be looked for as the result of its operation. 